\title{
US company comes under fire over patent on umbilical cord cells
}

Paris. Research groups from France, the Netherlands and the United Kingdom are planning to challenge a European patent on the use of stored stem cells from umbilical cord blood that was granted in May to the US company Biocyte Corporation. Such cells are widely thought to hold considerable therapeutic promise for bone marrow transplantation and gene therapy.

Biocyte's patent covers "hematopoietic stem and progenitor cells of neonatal or fetal blood, that are cryopreserved, and the therapeutic uses of such stem and progenitor cells upon thawing". The patent would give Biocyte rights over making, keeping, selling, disposing, importing and exporting stem cells from cord blood, as well as their therapeutic uses.

The research groups opposing the patent are all members of Eurocord, the European Cord Blood Bank which involves 14 European teams. Acting on behalf of the European Group for Blood and Marrow Transplantation, they say their main opposition to the patent is on moral grounds.

In the past, researchers have held back from patenting the various sources of stem cells, such as bone marrow, fetal liver, thymus and spleen, that can be used for transplantation. "We strongly feel that cord blood should not be patented," says Frederik Falkenburg, of the Department of Haematology at Leiden University Hospital in the Netherlands. "We believe is it not ethical to patent a human tissue."

Another critic is Eliane Gluckmann, a researcher at the Hôpital St Louis in Paris, who says that the patent contravenes a resolution approved by the International Society of Transplantation that parts of the human body should not be commercialized, and that organ donations should be free (see page 108). Others are concerned that the potential threat of expensive litigation may discourage companies and research groups from exploring new uses for cord blood cells.

Gluckmann says that Biocyte's patent could, in principle, allow it to prevent cord blood banks from operating, or at least require them to pay licences. Jean Dausset, Nobel laureate for physiology or medicine in 1980 , says he is "scandalized" by industry's "seizure" of bone marrow transplants.

Gluckmann is leading the European campaign to challenge the patent. In 1988 , working in collaboration with the patent holders, her group was the first to successfully use stem cells from umbilical cord in bone marrow transplants, transfusing a child with Fanconi's anaemia (an often-fatal

genetic disorder that affects red blood cells) with cord blood from its unaffected sibling.

Rodman Rockefeller, a director of Biocyte, confirms that the company is keen to secure licenses world-wide for its patented technology. "We feel it is an important discovery that will become more so over time," he says, adding that any opposition to the European patent will be aggressively challenged. But he says Biocyte is "willing to license its rights under its

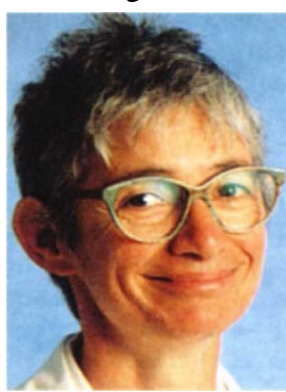

Gluckmann: leading challenge to patent. bone marrow transplants carried out in 1994 alone - physicians believe that the technique holds considerable promise.

Cord blood is a valuable source of stem cells, which can produce red and white blood cells, as well as platelets. Transplants of these stem cells are widely considered to be more effective than the conventional practice of taking stem cells from bone marrow donors, which is expensive, and painful for donors.

ViaCord, the leading US commercial cord blood bank, estimates that 9,000 patients die each year waiting on a bone marrow transplant. In contrast, umbilical cord blood transplants can be stored frozen, and are available immediately off the shelf.

Cord-blood stem cells also provoke less of an immune response, considerably reducing the risk of graft versus host disease. The technique could be used to treat cancers and other diseases, such as leukaemia, advanced solid stage tumours and genetic disorders, through bone marrow transplantation and gene therapy.

Moreover, genes seem to be easier to introduce into cord blood stem cells than into those from other sources, while introduced genes would in theory be expressed in all their blood cell progeny. The US National Institutes of Health has invested \$37 million on research into cord-blood transplantation, and plans to establish four cord-blood banks.

The European groups say that their main complaint is that the patent is unethical. But they also believe that it does not meet the legal criteria of novelty and 'non-obviousness'.

Falkenburg says he is confident that the critics of the patent will be able to show that it does not describe a novel invention. The use of cord blood, he asserts, "is not an invention by one group, but a logical development [of research carried out by several groups]; the idea was not new".

In the United States, Biocyte's patent was challenged in 1993 by Cryo-Cell International, a company based in New York. This led the US patent office to open a re-examination in the same year. Biocyte has appealed this decision and no final judgement has yet been made. Cynthia Fisher, president and chief executive officer of ViaCord, says that Biocyte's technology consists merely of "known cryopreservation techniques that have been utilized for bone marrow for decades".

Over the past few weeks, the European researchers have been trawling through the medical literature for evidence to support their case. They claim that various papers dating back to 1977 describe similar techniques to the patent.

But the paper that may clinch the case, says Falkenburg, is a Spanish $\mathrm{PhD}$ thesis, published in 1985 , which explicitly states, under the heading "Potential clinical uses of cord blood", that cord blood contains sufficient hematopoietic cells to carry out a transplant. "We think this will show that the patent is not inventive", says Falkenburg.

Adriane Antler, a lawyer with Pennie \& Edmonds, the firm representing Biocyte, however, dismisses such claims. "People are now jumping on the bandwagon," she says. But the patented process, she adds, "was not evident at all at the time of the filing of the patent".

Declan Butler

\section{'Relief' in Russia}

Moscow. "Most Russian scientists will have given a sigh of relief that our country will continue to develop in a direction chosen by its people," says Boris Saltykov, Russia's minister of science and technology, referring to last week's reelection of president Boris Yeltsin.

Speaking in Moscow on Monday, Saltykov said the main result of the presidential election was that "we are now able to plan our activities for years ahead, rather than speculate on what could happen in a month or two". 